\title{
Fixed bed reduction of hematite under alternating reduction and oxidation cycles
}

\author{
Ronald W. Breault ${ }^{* 1}$ and Esmail R. Monazam ${ }^{2}$ \\ ${ }^{1}$ National Energy Technology Laboratory \\ U. S. Department of Energy \\ 3610 Collins Ferry Rd. \\ Morgantown, West Virginia 26507-0880 \\ ${ }^{2}$ REM Engineering Services, PLLC \\ 3537 Collins Ferry Rd. \\ Morgantown, West Virginia 26505
}

\begin{abstract}
The rate of the reduction reaction of a low cost natural hematite oxygen carrier for chemical looping combustion was investigated in a fixed bed reactor where hematite samples of about $1 \mathrm{~kg}$ were exposed to a flowing stream of methane and argon. The investigation aims to develop understanding of the factors that govern the rate of reduction with in larger reactors as compared to mostly TGA investigations in the literature. A comparison of the experimental data with a model indicated that reaction between the methane and the iron oxide shows multi-step reactions. The analysis also shows that the conversion occurs with a process that likely consumes all the oxygen close to the surface of the hematite particles and another process that is likely controlled by the diffusion of oxygen to the surface of the particles. Additional analysis shows that the thickness of the fast layer is on the order of 8 unit crystals. This is only about $0.4 \%$ of the hematite; however, it comprises about 20 to $25 \%$ of the conversion for the 10 min reduction cycle.
\end{abstract}

Key Words: Chemical Looping Combustion, Fixed Bed Reactor, Hematite Reduction

\section{Introduction}

Over the past couple of decades, anthropogenic $\mathrm{CO}_{2}$ has been proposed as the reason for climate changes. Whether or not these $\mathrm{CO}_{2}$ increases have led to climate change or are the result of climate change, it is important to investigate technology options that can reduce and control $\mathrm{CO}_{2}$ emissions. The U.S. Department of Energy has set goals for carbon capture systems at $90 \%$ carbon dioxide $\left(\mathrm{CO}_{2}\right)$ capture with less than a $35 \%$ increase in cost of electricity [1]. There are four main categories of these technologies that can achieve these goals: pre-combustion, post-combustion, oxy-fuel and chemical looping [2]. The work presented in this paper looks into the reduction performance of a fixed bed chemical looping system.

Chemical looping is a new name to a relatively old concept that was utilized in the early 1900 s for the coal gasification technology called the Steam-Iron Process and again in the late 1960s and 1970s for another gasification technology which was called the $\mathrm{CO}_{2}$ Acceptor Process [3]. The terminology, chemical looping, was introduced in the 1990s to refer to a cyclic process in which an oxygen rich solid was contacted with a fuel such as natural gas to reduce the oxygen rich solid to form carbon dioxide and

\footnotetext{
*Corresponding author: Tel. 304-285-4486; fax: 304-285-4403; email: ronald.breault@netl.doe.gov
} 
water (combustion products). The reduced solid could then be transferred to another vessel and reoxidized. The cycling of the oxygen carrier between the reducer vessel and the oxidizer vessel is now termed chemical looping combustion. A conceptual process diagram is shown in Fig. 1. In this figure, a bed of the oxygen carrying solid particles is fluidized with a recycle stream of $\mathrm{CO}_{2}$ and steam. Fuel (methane) is introduced to this reactor to produce $\mathrm{CO}_{2}$ and water according to the chemical reaction noted below:

$$
\mathrm{CH}_{4}+4 \mathrm{MO} \rightarrow \mathrm{CO}_{2}+2 \mathrm{H}_{2} \mathrm{O}+4 \mathrm{M}
$$

where MO represents the oxygen rich solid, usually a metal oxide and M represents the reduced carrier. The combustion products exit the process as shown while the reduced carrier is conveyed to the oxidizer through a loop seal to keep the gases apart. The reduced carrier is re-oxidized according to the chemical reaction

$$
4 \mathrm{M}+2 \mathrm{O}_{2} \rightarrow 4 \mathrm{MO}
$$

In the concept loop shown in Fig. 1, the re-oxidized carrier is separated from the oxygen depleted air (vitiated air) in the cyclone, passed through a loop seal and fed back to the reducer to complete the "loop".

Chemical looping combustion is under investigation around the world for power production because the technology allows for fuel conversion with easy $\mathrm{CO}_{2}$ separation [4-6]. The current investigation is aimed at evaluating hematite, a naturally occurring $\mathrm{Fe}_{2} \mathrm{O}_{3}$ mineral, as an oxygen carrier for natural gas fuels applications. $\mathrm{Fe}_{2} \mathrm{O}_{3}$ has been cited as a potential carrier in numerous research publications [7-24] with many of these focusing on the development of required kinetics from TGA experimental investigations for scale-up of this technology.

In an effort to jump start the chemical looping combustion technology, the Office of Research and Development at the US Department of Energy's National Energy Technology Laboratory is focused on a two pronged (experimental and modeling) approach to introduce and develop chemical looping combustion. In one aspect of this work, NETL-ORD has been investigating natural gas chemical looping with hematite. The work presented herein has two purposes. The first is to provide model validation data such that large reactors can be designed using modern CFD approaches that NETL is pioneering. The second is to provide possible operational assessment on small batch systems for early technology adoption. In this second objective, it has been thought that in the current unconstrained carbon world that early adopters might be found for industrial applications that can utilize both the carbon dioxide and the process heat. One such application that has been considered is for a small cyclic batch unit at a green house, where the $\mathrm{CO}_{2}$ can be used to accelerate the plant growth. Therefore, to accomplish both of these objectives, small scale cyclic tests were carried out in a batch unit. The experimental results are discussed below.

\section{Literature Review of $\mathrm{Fe}_{2} \mathrm{O}_{3}$ Reduction}

Numerous researchers are investigating various naturally occurring and manufactured iron oxide based carriers for reduction with methane [5-24]. These are summarized in Tab. 1. Of particular interest is the work of Abad et al. [9], as they have put forward the most advanced and complete model for the reduction of ilmenite. Ilmenite is a naturally occurring iron and titanium mineral in the form of $\mathrm{FeTiO}_{3}$. The actual material tests by Abad et al. [9] consisted of $94.3 \%$ ilmenite with the balance being rutile $\left(\mathrm{TiO}_{2}\right)$ and hematite $\left(\mathrm{Fe}_{2} \mathrm{O}_{3}\right)$. The material had an Fe to Ti ratio of approximately 1. Abad et al. [9] found the reactions of ilmenite with methane to follow the reaction scheme noted below: 
82

83

84

85

86

87

88

89

90

91

92

93

94

95

96

97

98

99

100
Reduction with methane

$\left(\mathrm{Fe}_{2} \mathrm{O}_{3} \cdot \mathrm{TiO}_{2}\right)+\mathrm{TiO}_{2}+\mathrm{CH}_{4} \rightarrow \mathrm{CO}+2 \mathrm{H}_{2}+2 \mathrm{FeTiO}_{3}$

$3 \mathrm{Fe}_{2} \mathrm{O}_{3}+\mathrm{CH}_{4} \rightarrow \mathrm{CO}+2 \mathrm{H}_{2}+2 \mathrm{Fe}_{3} \mathrm{O}_{4}$

$3 \mathrm{Fe}_{2} \mathrm{O}_{3}+\mathrm{CO} \rightarrow \mathrm{CO}_{2}+2 \mathrm{Fe}_{3} \mathrm{O}_{4}$

$3 \mathrm{Fe}_{2} \mathrm{O}_{3}+\mathrm{H}_{2} \rightarrow \mathrm{H}_{2} \mathrm{O}+2 \mathrm{Fe}_{3} \mathrm{O}_{4}$

After cycling numerous times, Abad et al. [9] found that the titanium migrated to the center as the iron migrated to the shell of the particles and the following reactions best described the reduction process of a $\mathrm{Fe}_{2} \mathrm{O}_{3}$ reactive particle having an inert core.

Reduction with methane

$\mathrm{Fe}_{2} \mathrm{O}_{3}+\mathrm{CH}_{4} \rightarrow \mathrm{CO}+2 \mathrm{H}_{2}+2 \mathrm{FeO}$

Reduction with carbon monoxide

$\mathrm{Fe}_{2} \mathrm{O}_{3}+\mathrm{CO} \rightarrow \mathrm{CO}_{2}+2 \mathrm{FeO}$

Reduction with hydrogen

$\mathrm{Fe}_{2} \mathrm{O}_{3}+\mathrm{H}_{2} \rightarrow \mathrm{H}_{2} \mathrm{O}+2 \mathrm{FeO}$ 
101 Tab. 1. $\mathrm{Fe}_{2} \mathrm{O}_{3}$ reduction work with methane

\begin{tabular}{|c|c|c|c|c|c|c|c|c|}
\hline Author & Reactor Type & $\begin{array}{c}\text { Sample } \\
\text { Size (mg) }\end{array}$ & $\begin{array}{l}\text { Particle Size } \\
\qquad(\mu \mathrm{m})\end{array}$ & $\begin{array}{c}\text { BET } \\
\text { Surface } \\
\text { Area } \\
\left(\mathrm{m}^{2} / \mathrm{g}\right)\end{array}$ & $\begin{array}{c}\text { Sample } \\
\text { Frequency } \\
(\mathrm{Hz})\end{array}$ & $\begin{array}{l}\text { Reduction } \\
\text { Gas }\end{array}$ & $\begin{array}{c}\text { Reaction } \\
\text { Control }\end{array}$ & Carrie Form \\
\hline $\begin{array}{l}\text { Abad et al. } \\
\text { (2007) [8] }\end{array}$ & $\begin{array}{c}\text { Circulating } \\
\text { bed }\end{array}$ & 110,000 & 90 to 212 & - & - & $\begin{array}{l}\text { Natural gas } \\
\left(88 \% \mathrm{CH}_{4}\right)\end{array}$ & - & $\begin{array}{l}60 \% \mathrm{Fe}_{2} \mathrm{O}_{3} \\
\text { and } \mathrm{Al}_{2} \mathrm{O}_{3}\end{array}$ \\
\hline $\begin{array}{l}\text { Abad et al. } \\
\text { (2011) [9] }\end{array}$ & TGA & 50 & 150 to 300 & .8 & - & $\begin{array}{c}\mathrm{CH}_{4} \text { and } \\
\text { steam }\end{array}$ & $\begin{array}{l}\text { Shrinking } \\
\text { grain }\end{array}$ & $\begin{array}{l}\mathrm{FeTiO3} \\
\text { (Ilmenite }\end{array}$ \\
\hline $\begin{array}{l}\text { Adanez et al. } \\
(2005)[10]\end{array}$ & $\begin{array}{l}\text { Bubbling } \\
\text { fluidized bed }\end{array}$ & $2 \times 10^{5}$ & 100 to 300 & - & - & $\begin{array}{c}\mathrm{CH}_{4} \\
\text { saturated } \\
\text { with } \mathrm{H}_{2} \mathrm{O} \\
\text { vapor }\end{array}$ & - & $\begin{array}{l}60 \% \mathrm{Fe}_{2} \mathrm{O}_{3} \\
\text { and } \mathrm{Al}_{2} \mathrm{O}_{3}\end{array}$ \\
\hline $\begin{array}{l}\text { Cho et al. } \\
(2002)[11]\end{array}$ & $\begin{array}{l}\text { Bubbling } \\
\text { fluidized bed }\end{array}$ & $\begin{array}{c}15,000 \text { to } \\
60,000\end{array}$ & 125 to 250 & - & - & $\mathrm{CH}_{4}$ & - & $\begin{array}{c}\mathrm{Fe}_{2} \mathrm{O}_{3} \text { and } \\
\mathrm{Al}_{2} \mathrm{O}_{3}\end{array}$ \\
\hline $\begin{array}{l}\text { Gayán et al. } \\
(2012)[12]\end{array}$ & $\begin{array}{c}\text { Bubbling } \\
\text { fluidized bed }\end{array}$ & $2 \times 10^{5}$ & 100 to 300 & 9.3 & - & $\mathrm{CH}_{4}$ in $\mathrm{N}_{2}$ & - & $\begin{array}{c}\mathrm{Fe}_{2} \mathrm{O}_{3} \text { on } \\
\mathrm{Al}_{2} \mathrm{O}_{3}\end{array}$ \\
\hline $\begin{array}{l}\text { Go et al. } \\
\text { (2008)[13] }\end{array}$ & TGA & 7 to 8 & 125 & 9.055 & 0.033 & $\mathrm{CH}_{4}$ & Diffusion & $\mathrm{Fe}_{2} \mathrm{O}_{3}$ \\
\hline $\begin{array}{l}\text { He et al. } \\
(2007)[14]\end{array}$ & Fixed Bed & 60,000 & $\begin{array}{c}1500 \\
\text { to } \\
2000\end{array}$ & - & - & $\begin{array}{l}\text { Humidified } \\
\mathrm{CH}_{4} \text { in } \mathrm{Ar}\end{array}$ & - & $\begin{array}{l}80 \% \mathrm{Fe}_{2} \mathrm{O}_{3} \\
\text { and } \mathrm{Al}_{2} \mathrm{O}_{3}\end{array}$ \\
\hline $\begin{array}{l}\text { Johansson et } \\
\text { al. (2004) [15] }\end{array}$ & $\begin{array}{l}\text { Bubbling } \\
\text { fluidized bed }\end{array}$ & $\begin{array}{c}10,000 \\
\text { and } \\
15,000\end{array}$ & $\begin{array}{l}125 \\
\text { to } \\
180\end{array}$ & - & - & $\begin{array}{c}\mathrm{CH}_{4} \text { and } \\
\text { steam }\end{array}$ & $\begin{array}{l}\text { Diffusion for } \\
\text { materials } \\
\text { that have } \\
\text { seen high } \\
\text { temperatures }\end{array}$ & $\begin{array}{l}\mathrm{Fe}_{2} \mathrm{O}_{3} \text { on } \\
\mathrm{MgAl}_{2} \mathrm{O}_{4}\end{array}$ \\
\hline $\begin{array}{l}\text { Leion et al. } \\
\text { (2008) [16] }\end{array}$ & $\begin{array}{l}\text { Bubbling } \\
\text { fluidized bed }\end{array}$ & 15,000 & $\begin{array}{l}125 \\
\text { to } \\
180\end{array}$ & - & - & $\mathrm{CH}_{4}$ & - & $\begin{array}{c}\mathrm{FeTiO3} \\
\text { (Ilmenite) }\end{array}$ \\
\hline $\begin{array}{l}\text { Mattisson et } \\
\text { al. (2004) [17] }\end{array}$ & $\begin{array}{l}\text { Bubbling } \\
\text { fluidized bed }\end{array}$ & 10,000 & $\begin{array}{l}125 \\
\text { to } \\
180\end{array}$ & - & - & $\begin{array}{c}\mathrm{CH}_{4} \text { and } \\
\text { steam }\end{array}$ & $\begin{array}{l}\text { Kinetic to } \\
\text { Diffusion }\end{array}$ & $\begin{array}{c}60 \% \mathrm{Fe}_{2} \mathrm{O}_{3} \\
\text { and } \mathrm{Al}_{2} \mathrm{O}_{3}\end{array}$ \\
\hline $\begin{array}{l}\text { Mendiara et al. } \\
\text { (2012) [18] }\end{array}$ & $\begin{array}{l}\text { Bubbling } \\
\text { fluidized bed }\end{array}$ & $3 \times 10^{5}$ & $\begin{array}{l}150 \\
\text { to } \\
300\end{array}$ & .9 & - & $\begin{array}{c}\mathrm{CH}_{4} \text { and } \\
\text { steam in } \mathrm{N}_{2}\end{array}$ & - & $\begin{array}{l}71 \% \mathrm{Fe}_{2} \mathrm{O}_{3} \\
\text { and } \mathrm{Al}_{2} \mathrm{O}_{3}\end{array}$ \\
\hline $\begin{array}{l}\text { Moghtaderi et } \\
\text { al. (2010) [19] }\end{array}$ & TGA & 28 to 40 & 30 to 40 & 3.5 & 1 & $\begin{array}{c}\mathrm{CH}_{4} \text { and } \\
\text { steam }\end{array}$ & - & $\mathrm{Fe}_{2} \mathrm{O}_{3}$ \\
\hline Monazam et & TGA & 60 & & .1 & 1 & $\mathrm{CH}_{4}$ in $\mathrm{N}_{2}$ & Kinetic and & $\mathrm{Fe}_{2} \mathrm{O}_{3}$ \\
\hline
\end{tabular}




\begin{tabular}{|c|c|c|c|c|c|c|c|c|}
\hline al. (2013) [20] & & & & & & & $\begin{array}{c}\text { Diffusion } \\
\text { (JMA) }\end{array}$ & \\
\hline $\begin{array}{l}\text { Son et al. } \\
(2006) \text { [21] }\end{array}$ & $\begin{array}{l}\text { Circulating } \\
\text { bed }\end{array}$ & $6 \times 10^{5}$ & $\begin{array}{l}106 \\
\text { to } \\
150\end{array}$ & - & 0.04 & $\mathrm{CH}_{4}$ & - & $\begin{array}{c}\mathrm{Fe}_{2} \mathrm{O}_{3} \text { on } \\
\mathrm{TiO}_{2}, \mathrm{Al}_{2} \mathrm{O}_{3} \\
\text { and } \\
\text { bentonite }\end{array}$ \\
\hline $\begin{array}{l}\text { Zhang et al. } \\
\text { (2012) [22] }\end{array}$ & TGA & - & - & 4 & - & $\mathrm{CH}_{4}$ & - & $\begin{array}{l}75 \% \mathrm{Fe}_{2} \mathrm{O}_{3} \\
\text { and } \mathrm{Al}_{2} \mathrm{O}_{3}\end{array}$ \\
\hline $\begin{array}{l}\text { Ku et al. } \\
\text { (2014) [23] }\end{array}$ & Fixed bed & $2.9 \times 10^{6}$ & - & - & & $\mathrm{CH}_{4}$ in $\mathrm{N}_{2}$ & - & $\begin{array}{c}\mathrm{Fe}_{2} \mathrm{O}_{3} \text { and } \\
\mathrm{Al}_{2} \mathrm{O}_{3}\end{array}$ \\
\hline $\begin{array}{l}\text { Y. Zhang et al. } \\
\text { (2014) [24] }\end{array}$ & TGA & 10 to 15 & 75 to 150 & - & - & $\mathrm{CH}_{4}$ in $\mathrm{N}_{2}$ & - & $\begin{array}{c}\mathrm{Fe}_{2} \mathrm{O}_{3} \text { and } \\
\mathrm{Al}_{2} \mathrm{O}_{3}\end{array}$ \\
\hline Current work & Fixed Bed & $10^{6}$ & 230 & .1 & 1 & $\mathrm{CH}_{4}$ in $\mathrm{Ar}$ & $\begin{array}{c}\text { Discussed } \\
\text { below }\end{array}$ & $\mathrm{Fe}_{2} \mathrm{O}_{3}$ \\
\hline
\end{tabular}

122
Based upon this finding, it was initially hypothesized that the hematite would behave similar to the cycled ilmenite - an assumption that will be shown not to hold in the analysis provided below. Abad et al. [9] found that the ilmenite methane reaction was kinetically controlled and followed the following equation

$$
\frac{t}{\tau_{i}}=1-(1-X)^{1 / 3}
$$

In the above equation, $X$ is the conversion of $\mathrm{Fe}_{2} \mathrm{O}_{3}$ and $\tau_{i}$ is the time for complete conversion which is given by

$$
\tau_{i}=\frac{\rho_{m} r_{g}}{b k_{s i} c_{i}}
$$

where $\rho_{m}$ is the molar density of $\mathrm{Fe}_{2} \mathrm{O}_{3}, r_{g}$ is the grain radius, $b$ is the stoichiometric coefficient, $k_{s i}$ is the reaction rate, $C_{i}$ is the reacting gas concentration and the index $i$ stands for $\mathrm{CH}_{4}, \mathrm{CO}$ or $\mathrm{H}_{2}$.

Monazam et al. [20], working at the US Department of Energy, National Energy Technology Laboratory (NETL), have been exploring the kinetics of North American iron containing ores, primarily hematite from Canada [20, 25-26]. Monazam et al. [20] found the reaction of methane with the Canadian hematite to occur with a two reaction process. ( $\mathrm{R}_{1}$ and $\left.\mathrm{R}_{2}\right)$ according to equations 14 and 15 as opposed to the single step process obtained by Abad.

$\mathrm{R}_{1}: \quad 3 \mathrm{CH}_{4}+8 \mathrm{Fe}_{2} \mathrm{O}_{3} \rightarrow 16 \mathrm{FeO}+2 \mathrm{CO}_{2}+\mathrm{CO}+3 \mathrm{H}_{2} \mathrm{O}+3 \mathrm{H}_{2}$

$\mathrm{R}_{2}: \quad 4 \mathrm{CH}_{4}+27 \mathrm{Fe}_{2} \mathrm{O}_{3} \rightarrow 18 \mathrm{Fe}_{3} \mathrm{O}_{4}+2 \mathrm{CO}_{2}+2 \mathrm{CO}+3 \mathrm{H}_{2} \mathrm{O}+5 \mathrm{H}_{2}$

Based upon TGA experiments, Monazam et al. [20] showed that the kinetics for the first reaction $\left(\mathrm{R}_{1}\right)$ to be kinetic controlled and to follow the rate equations

$$
\frac{d X_{1}}{d t}=k_{1}\left(w_{1} X_{\infty}-X_{1}\right)
$$


where $k_{l}=$ rate constant for the first mechanism $\left(\min ^{-1}\right), w_{l}=$ weight factor for the first mechanism, $X_{l}=$ conversion of $\mathrm{Fe}_{2} \mathrm{O}_{3}$ by $\mathrm{R}_{1}$ at any time $\mathrm{t}, X_{\infty}=$ equilibrium conversion, $\mathrm{t}=$ time $(\mathrm{min}), \mathrm{y}_{\mathrm{CH} 4}$ is the methane mole fraction and $\mathrm{T}$ is the temperature $(\mathrm{K})$.

In the same work, Monazam et al. [20] showed that the second reaction $\left(\mathrm{R}_{2}\right)$ to be controlled according to a nucleation and growth mechanism that behaved according to the equations

$$
\begin{aligned}
& \frac{d X_{2}}{d t}=k_{2}\left(w_{2} X_{\infty}-X_{2}\right)\left(-\ln \left(1-\frac{X_{2}}{w_{2} X_{\infty}}\right)\right)^{1 / 2} \\
& k_{2}=133 y_{C H_{4}}^{1.06} e^{\frac{-4731.2}{T}}
\end{aligned}
$$

where $k_{2}=$ rate constant for the first mechanism $\left(\right.$ min. $\left.^{-1}\right), w_{2}=$ weight factor for the second mechanism, and $X_{2}=$ conversion of $\mathrm{Fe}_{2} \mathrm{O}_{3}$ by $\mathrm{R}_{2}$ at any time $t$. Three other relationships are needed for $w_{1}, w_{2}$ and $X_{\infty}$.

$$
w_{1}+w_{2}=1
$$

The other authors [11-19, 21-22] worked primarily with supported $\mathrm{Fe} 2 \mathrm{O} 3$ or mixtures prepared with various binders such as $\mathrm{Al}_{2} \mathrm{O}_{3}$ or $\mathrm{SiO}_{2}$. Furthermore, most use steam or at least humidified $\mathrm{CH}_{4}$ to inhibit coke formation due to the $\mathrm{CH}_{4}$ cracking. In general, the rate improved in these studies as the initial fabricated particle became conditioned after several cycles. This is in the opposite direction with the current study which is discussed below for the naturally occurring Canadian hematite reactions in a fixed bed.

Also, with regard to Tab. 1, there are some additional points of interest. The first of these is that Go et al. [13] found the reaction with $\mathrm{Fe}_{2} \mathrm{O}_{3}$ and methane to be diffusion controlled. That work used the smallest sample size reported. Also, Johansson et al. [15] found that materials that had seen high temperatures were diffusion controlled.

\section{Experimental Facility and Test Procedure.}

The test facility consists of a reactor which is fed from gas tanks (methane, argon, and oxygen) through the mass flow controllers which allow precise control of the gases. The reactor has an overall height 62.3 $\mathrm{cm}$, an internal diameter of $6.0 \mathrm{~cm}$ in the lower reactor zone which is $34.8 \mathrm{~cm}$ high and $10.1 \mathrm{~cm}$ freeboard region. The reactor feed gases are fed to the reactor through a sintered quartz distributor plate. The temperature is measures at the bottom, middle and top of the $6.0 \mathrm{~cm}$ reacting zone. The product gases exit the reactor at the top through a $0.05 \mathrm{~cm}$ ID outlet tube. It is surrounded by heaters to control the reaction temperature. The feed gas reacts with the hematite inside the vessel and the product gases are directed through a mass spectrophotometer gas analyzer before it exits the system.

As noted above, experiments are being conducted for two purposes: to provide experimental validation of the TGA data and to provide an assessment of a small cyclic batch chemical looping unit for 
early proof of concept adoption in a commercial setting where both the heat and $\mathrm{CO}_{2}$ can be utilized. This latter objective put some constraints on the test conditions. Tests need to be carried out in a low methane flow rate to avoid coke formation. Steam, the expected diluent in larger conceptual units, gasifies the deposited carbon. In this smaller application steam is not available and methane concentrations need to be kept quite small, less than $10 \%$. Therefore, in this initial assessment, two series of tests were conducted at $800 \mathrm{C}$, one at approximately $7.23 \% \mathrm{CH}_{4}$ by volume and the other at approximately $5 \% \mathrm{CH}_{4}$ by volume with the balance being argon. The tests conducted at $7.23 \% \mathrm{CH}_{4}$ were conducted at feed flow rate corresponding to a superficial velocity of $2.7 \mathrm{~cm} / \mathrm{s}$ while the other test series was run at a corresponding velocity of $7.3 \mathrm{~cm} / \mathrm{s}$. The operating data for the two test series is summarized in Tab. 2. Tests in each series were conducted over a two day period and conditions varied slightly during each series between the days. The material was added to the reactor (nominally $1050 \mathrm{~g}$ ) and the reactor closed up and the tests begun. The material properties are presented in Tab. 3.

Tab.2. Operating Conditions, Fixed $T_{\text {in }}(800 \mathrm{C})$ and Pressure (170 kPa)

\begin{tabular}{|l|c|c|c|c|}
\hline & \multicolumn{2}{|c|}{ Series 1 } & \multicolumn{2}{c|}{ Series 2 } \\
\hline & Day 1 & Day 2 & Day 1 & Day 2 \\
\hline Flow rate, $\mathrm{kg} / \mathrm{s}$ & $6.45 \mathrm{E}-05$ & $4.68 \mathrm{E}-05$ & $1.51 \mathrm{E}-04$ & $1.51 \mathrm{E}-04$ \\
\hline Superficial Velocity, $\mathrm{m} / \mathrm{s}$ & 0.0318 & 0.0231 & 0.0735 & 0.0734 \\
\hline $\mathrm{CH}_{4}$ mass fraction & 0.030 & 0.030 & 0.021 & 0.020 \\
\hline Cycles & $1-4$ & $5-9$ & $1-5$ & $6-10$ \\
\hline
\end{tabular}

Tab. 3. Material Properties.

\begin{tabular}{|c|c|c|}
\hline & Units & Value \\
\hline \multicolumn{3}{|l|}{ Composition } \\
\hline $\mathrm{Fe}_{2} \mathrm{O}_{3}$ & $\%$ & 95 \\
\hline Inert & $\%$ & 5 \\
\hline Particle Size & um & 200 \\
\hline Particle Density & $\mathrm{kg} / \mathrm{m}^{3}$ & 4770 \\
\hline \multicolumn{3}{|l|}{ Langmuir Surface Area } \\
\hline $800 \mathrm{C}$ & $\mathrm{m}^{2} / \mathrm{g}$ & 0.41 \\
\hline $900 \mathrm{C}$ & $\mathrm{m}^{2} / \mathrm{g}$ & 0.09 \\
\hline
\end{tabular}

The general experimental facility operation is summarized in Fig. 2. In this figure the temperature, gas flow rate and gas species mass fractions are shown. The temperature is ramped up to the operating temperature under an argon gas flow. Once the reactor temperature has stabilized at the set condition $\left(800{ }^{\circ} \mathrm{C}\right)$, the fuel (reduction) gas flow is initiated and maintained for 10 minutes. This can be seen in Fig. 2 by the dip in the argon mass fraction and an increase in the $\mathrm{CO}_{2}$ and $\mathrm{CH}_{4}$ mass fraction values. At this time, the fuel gas is switched off and the argon flow increased to purge the reactor of combustible gas for approximately 25 minutes prior to regenerating the hematite with air. The carrier is regenerated for 20 minutes after which the air flow is stopped and the reactor purged of oxygen prior to starting the next reduction cycle. The temperature for the process is essentially constant at $800{ }^{\circ} \mathrm{C}$ as seen by the temperature trace with the exception of a small rise $\left(15^{\circ} \mathrm{C}\right)$ in the gas temperature when air is introduced during regeneration. This temperature rise will be shown to affect the cyclic stability of the carrier in batch operation. 


\section{Results}

186

187

188

189

190

191

192

193

194

195

196

197

198

199

200

The gas composition data for methane, carbon monoxide and carbon dioxide are shown in Fig. 3 and 4 for tests series 1 and 2, respectively. In Fig. 3 and 4, the data for cycle 1 is significantly different than that for the other cycles in the test series. Looking at the $\mathrm{CH}_{4}$ mass fraction data for cycles 1,2 and 3 in Fig. 3, it can be seen that the exit concentration of methane for cycle 1 is significantly different from the values of cycles 2 and 3. Note, that a gas valve switching error occurred during the Series 1 , cycle 4 test rendering the data unusable and subsequently omitted from Fig. 3. An ANOVA analysis conducted at a 95\% confidence level showed that the mean values in cycles 1,2 and 3 were not the same but that the means for cycles 2 and 3 were the same. The same finding was obtained for cycles 1 through 5 and 2 through 5 for methane in Fig. 4. Other interesting features in the data can be seen by comparing Fig. 3 to Fig. 4. In this comparison, it can be seen most clearly in the methane curves that there is a sudden decrease in the exit mass fraction for cycles 4 through 10. Incidentally, 40 more cycles have been conducted on the Series 2 conditions showing the same phenomena. This decrease in the methane composition is simultaneously accompanied by an increase in the carbon monoxide concentration and in the hydrogen concentration as seen by examining Fig. 5. 
One last observation of the experimental results can be seen by looking at the $\mathrm{CO}_{2}$ curves in both

\section{Analysis and Discussion}

Recent modifications to the Barracuda CFD software have resulted in speed improvements significant enough that it can now be used as an expedient tool for data analysis. Therefore, a model of the MIR reactor was built using the Abad et al. [9] mechanism and kinetics. The details of the model parameters are presented in Tab. 4. A summary of the code and its sub-models can be found Breault and Huckaby [27]. The Abad et al.[9] kinetics for ilmenite greatly over predicted the $\mathrm{CO}_{2}$ product such that the amount of reactive $\mathrm{Fe}_{2} \mathrm{O}_{3}$ needed to be significantly reduced to produce comparable results. These are shown in Fig. 7. In Fig. 7, the experimental data for the first cycle is shown with the solid squares and that for the second cycle with solids circles. Note that the active $\mathrm{Fe}_{2} \mathrm{O}_{3}$ (33\% in Abad's mechanism) needed to be reduced to about $10 \%$ to reasonably model the first 40 s of the first cycle prior to over predicting the conversion to $\mathrm{CO}_{2}$ at times greater than $40 \mathrm{~s}$ as shown by the simulation data marked by the open diamonds. Looking at the simulation curve with $5 \%$ reactive $\mathrm{Fe}_{2} \mathrm{O}_{3}$ (open circles), it can be seen that the predicted $\mathrm{CO}_{2}$ at times less than about 150s shows significant differences when compared to the experimental data of the first cycle. However at times greater than $150 \mathrm{~s}$, the agreement is quite good. Looking at the second cycle, the predicted results (for $3 \%$ reactive $\mathrm{Fe}_{2} \mathrm{O}_{3}$ ) are quite similar with the experimental data, although it can be seen that the fit is not quite right and reducing the reactive content would give a better fit for the early times but misses the latter times as one can see that the slope of the model predictions (open triangles) is greater than the experimental data at large times. In summary, this plot gives two important clues to understanding the reaction with naturally occurring hematite and methane: (1) conversion to $\mathrm{CO}_{2}$ consists of multiple reactions with a fast reaction and a much slower reaction and (2) hematite and ilmenite do not react similarly even though the ilmenite kinetics are based upon and $\mathrm{Fe}_{2} \mathrm{O}_{3}$ shell and a $\mathrm{TiO}_{2}$ core. 


\begin{tabular}{|l|l|l|}
\hline Parameter & Value or Minimum & Maximum \\
\hline$\Delta \mathrm{x}$ & $\mathbf{4 . 1 3} \mathbf{~ m m}$ & $\mathbf{5 . 9 9} \mathbf{~ m m}$ \\
\hline$\Delta \mathrm{y}$ & $\mathbf{4 . 1 3} \mathbf{~ m m}$ & $\mathbf{5 . 9 9} \mathbf{~ m m}$ \\
\hline$\Delta \mathrm{z}$ & $\mathbf{4 . 5 2} \mathbf{~ m m}$ & $\mathbf{5 . 1 9} \mathbf{~ m m}$ \\
\hline$\Delta \mathrm{t}$ & $\mathbf{0 . 0 0 6} \mathrm{s}$ & $\mathbf{0 . 1 5} \mathbf{~}$ \\
\hline No. Clouds & $\mathbf{2 1 6 , 1 6 0}$ & \\
\hline No. Particles & $\mathbf{3 4 , 2 8 0 , 7 9 8}$ & \\
\hline No. Cells (Total) & $\mathbf{5 0 , 4 0 0}$ & \\
\hline No. Cells (Real) & $\mathbf{2 2 , 7 1 2}$ & \\
\hline Grid Technique & Cut Cell & \\
\hline Model & E-L Hybrid (PIC) & \\
\hline $\begin{array}{l}\text { Frictional } \\
\text { Shear Viscosity }\end{array}$ & $\begin{array}{l}\text { Harris-Crighton } \\
\text { Ps }=\mathbf{1 , ~ B ~}=\mathbf{3 ,} \mathbf{\varepsilon}=\mathbf{1 0}\end{array}$ & \\
\hline Turbulent Stress & N/A & \\
\hline Particle-Wall BC & $\begin{array}{l}\text { Smagorinsky } \\
\text { Cs }=\mathbf{0 . 0 1}\end{array}$ & \\
\hline Gas Boundary Condition & No slip & \\
\hline Equation of State & Ideal Gas & \\
\hline Energy Equations & $\begin{array}{l}\text { Compressible } \\
\text { no viscous heating }\end{array}$ & \\
\hline Drag & $\begin{array}{l}\text { Ergun/Wen-Yu } \\
\text { agglomeration } \\
\text { w/ 18 um cutoff }\end{array}$ & \\
\hline
\end{tabular}

The above findings are further supported from a side by side comparison of TGA results for the solid carrier conversion (defined as $\left(\right.$ mass $\left.\left._{\text {initial }}-\operatorname{mass}_{\text {final }}\right) /\left(\operatorname{mass}_{\text {initial }}-\operatorname{mass}_{\mathrm{FeO}}\right)\right)$ is plotted against time for the results by Abad et al. [9] for ilmenite and by Monazam et al. [20] for the Canadian hematite used in the present work. The differences in how the two ores react are quite apparent when the curves are placed side by side. The ilmenite data show a more or less typical first order rate law conversion versus time plot. A non- zero initial rate that is constant for about one third of the reaction time and then decaying to zero as the full conversion of the carrier is asymptotically approached. This behavior contrasts significantly with that for the hematite, which shows a period with a near zero initial rate that lasts approximately 2 minutes in duration. The reaction then ignites at a rate corresponding to that seen for the ilmenite material. Finally, the rapid reaction is somewhat extinguished leading to a period with a much slower reaction rate. Monazam et al. [20] found that the conversion of hematite occurred through two reactions as shown above; one rate having an initial non-zero value which occurred overall the times investigated and a second reaction that had an initial rate near or equal to zero during an induction period a high rate period that extinguished after a short period. This is consistent with the results herein as will be shown.

An example of the methane reaction rate data as a function of time for one of the tests is shown in Fig. 9. The shape of this curve as well as the shape of the $\mathrm{CO}_{2}$ product curves, particularly for cycle 1 in both sets of experiments, leads the author to believe that the rate is a combination of two reactions in parallel as was found by Monazam et al [20]. The time series reaction rate data was then approximated 
with the sum of two exponential functions as shown in Fig. 9. The overall fit for the sum of the two exponential curves and the experimental data has an $\mathrm{R}^{2}$ value greater than 0.99 . The area under the surface curve represents in the methane consumed in that reaction and is proportional to the mass loss of oxygen from the solid carrier particles. This ranges from about 0.1 to $0.5 \%$ of the carrier weight in the bed but as much as $25 \%$ of the conversion of the solid carrier over the $600 \mathrm{~s}$ of the reduction process. The area under the slow reaction curve, when extrapolated to zero corresponds to a carrier weight loss of

Now, knowing that the particle reacts rapidly with a thin shell at the surface and much slower with the bulk of the material, a reaction model can be identified. Therefore, a reaction model is proposed as follows, the overall reaction rate, $R_{T}$, is the sum of the surface reaction, $R_{s}$, and the core reaction, $R_{c}$.

$$
R_{T}=R_{s}+R_{c}
$$

Where these rates can be expressed as

$$
R_{s}=k_{s}\left(u, S_{A}, T, y_{g}\right) X_{S}^{n_{S}}
$$

and

$$
R_{c}=k_{c}\left(u, S_{A}, T, y_{g}\right) X_{c}^{n_{c}}
$$

Where the subscript, $s$, refers to the surface reaction and the subscript, $c$, to the core reaction. The rate constant, $k$, is a function of the gas velocity, $u$; the particle surface area, $S_{A}$; the temperature, $T$; and the gas concentration or mole fraction, $y_{g}$. Also, the solids conversion is represented by, $X$ and the superscript, $n$, represents the solids reaction order.

This model is applied to all the data for each series and each cycle. A typical plot of the results is shown in Fig. 10 for series 1, cycle 1. The sum of the surface and core models are compared to the experiment with an $\mathrm{R}^{2}$ value greater than $99 \%$. There is a slight deviation at the larger time values. This is, however, a relatively small error given the likely solids residence times ( 5 to $10 \mathrm{~min}$ ) in a fuel reactor. The reaction order with respect to the solids was obtained from the model fit. The order for the core reaction, $n_{s}$, was found to be equal to 2 . This is consistent with the stoichiometry proposed by Monazam et al. [20] which suggests this order ought to be near 2.6 which this appears to be. On the other hand, the reaction order for the surface reaction, $n_{f}$, was found to range from 4 to 12 with an average of 9 . This is also consistent with the stoichiometry proposed by Monazam et al. [20] for the surface reaction which suggests that the reaction order should approximately 7 which it appears to be. A similar level of agreement was found for all the other cycles, with $\mathrm{R}^{2}$ values for all cycles exceeding 0.99 . The area under the surface model in Fig. 10 is represents the methane consumed in this process step. This mass is represents a penetration depth on the order of 50 to $60^{\circ} \mathrm{A}$. Given that a unit cell for Fe $2 \mathrm{O} 3$ is on the order of $6.5^{\circ} \mathrm{A}$, the surface reaction occurs over a depth of about 8 unit cells. Since the grains are none porous (see Tab. 3) given the low surface area, for reactions to occur beyond this limit set by the surface reaction process oxygen must migrate to the surface through vacancy diffusion [28]. 
The rate constant for the surface reaction, $k_{s}$, for all the data is plotted versus cycle number in Fig. 11 . General observations are that there is a slight decay (20 to 25\%) in the rate with cycle number and that the rate constant for the high velocity series (Series 2) is about 3 to 4 times greater than that for the low velocity data.

Noting that in the proposed reaction rate model and that these experiments were conducted at a single temperature, the reaction rate constant reduces to a function of the gas concentration, the particle surface area and the gas velocity;

$$
k_{s}=k_{S}\left(u, S_{A}, y_{g}\right)
$$

The velocity effect is accounted for using the particle Sherwood Number. According to Kunii and Levenspiel [29] the Sherwood Number in fixed beds is a power function of the Reynolds Number. A fit of the data presented in Kunii and Levenspiel [29] gives the following relationship

$$
S h=0.1061 R e^{1.6}
$$

Therefore, normalizing the reaction rate constant by the ratio of $\left(u / u_{l}\right)$ raised to the 1.6 power where $(u)$ is either the high velocity for the Series 2 data set or the low velocity for the Series 1 data should correct for the velocity.

The effect of methane concentration was analyzed by normalizing both sets of data by the inlet mass fraction of methane. It was postulated that since the fast reaction being discussed here is controlled by how fast that methane can get to the surface that the reaction front in the fixed bed would be quite sharp. This implies that the inlet gas concentration should give a better relationship between the rate constant and the functionality with concentration than using the mean value of the feed and exit concentrations during the reaction period. The results of this assumption can be seen in Fig. 12 in which the velocity normalized rate constant is divided by the inlet mass fraction. The comparison is quite good for the last five cycles or so. The reaction order was explored by assessing improvements to the agreement in the later cycles by changing the power that the methane mass fraction was raised. The best fit was for a reaction order of one.

Finally, the fast reaction rate constant was corrected for the changing surface area with cycle number (see material in Supplemental Data for this relationship). Applying this functionality by normalizing all the data in both sets by the ratio of the surface area at each cycle by the surface area for the first cycle $\left(\mathrm{SA}_{\mathrm{i}} / \mathrm{SA}_{1}\right)$ where ' $\mathrm{i}$ ' is the cycle being analyzed. This brought all the data for both cycles to reaction rate constant corrected for velocity, surface area and methane concentration to a value of 0.028 at a 95\% confidence interval as found through an ANOVA analysis of the Series means as is seen in Fig. 12.

A similar analysis was conducted for the core reaction where the reaction rate constant is presented in Fig. 13 as was done for the surface reaction. The most obvious trend is the decay in the rate constant with increasing cycle number. After correcting for the gas velocity, the particle surface area and the methane concentration the rate constants for the two series converged to an average of 29.2 with a 95\% confidence level as determined by an ANOVA analysis of the two series means. This data is presented in Fig. 14. 
The above findings have numerous implications in the design of commercial chemical looping combustion systems. The first, and likely the most important, finding is that regardless of the carrier type, heat generated within the particle during its oxidation in the air reactor has the potential to make permanent and adverse changes to the particle morphology as indicated by the strong effect seen above and reported by Johansson et al. [15]. In conventional, heterogeneous carbonaceous fuel combustion, the reaction products are gaseous and convect the heat of reaction out of the particle. This is not the case with the oxidation of chemical looping carriers. In this situation, the products are solid, keeping the heat of reaction within the particle. This causes locally high temperatures near the reaction sites and morphological changes of the carrier. The more dense the carrier, the more pronounced the morphological changes. By observing that fluidized bed operation at NETL/DOE and reported in the literature do not appear to have a significant decay in the performance with the limited number of cycles, indicates that if the particle temperature can be controlled by high heat transfer rates the carrier performance will be longer lasting.

Another finding is that both natural hematite and manufactured carriers (Johansson et al. [15]) both have a very fast surface reaction with methane followed by slower reaction(s) that progress by oxygen transport from the bulk of the lattice to the surface. The smaller the grains, the faster this process will occur. Grain size in naturally occurring ores cannot be controlled. This is the most likely reason why some hematite ores have poor reactivity and others do not. It also implies that manufactured carriers that are made with smaller particles should have better performance than carriers made with relatively large particles.

Abad's [9] particle reaction scheme for ilmenite was presented above in Equation 13 for shrinking core particle. A more likely scheme for the hematite is presented conceptually in Fig. 15. In this case, the particle consists of grains that are dense nonporous $\mathrm{Fe}_{2} \mathrm{O}_{3}$ masses. Also, the grains have germs or nucleuses where reactions are favored. After initially removing the oxygen in these regions, the reaction proceeds by oxygen transport through the lattice to the germ at the surface, a relatively slow process for deep reduction. Incidentally, the oxidation of a deeply reduced particle will also be relatively slow as oxygen diffuses back into the solid lattice.

\section{Conclusion}

Fixed bed reduction-oxidation cycles were conducted using Canadian hematite in a nominally 5 $\mathrm{cm}$ diameter reactor with approximately $1 \mathrm{~kg}$ of the hematite. The hematite, as well as manufactured carriers utilizing $\mathrm{Fe} 2 \mathrm{O} 3$ as the oxygen source, have a very fast surface reaction that depletes the gain surface to a depth of about 8 unit cells and then proceeds by one or more reactions that involve oxygen diffusing out of the lattice to the surface. There is an adverse effect on the rate and capacity caused by particle exposure to high temperatures during the oxidation half of the cycle. Increased heat transfer during the oxidation cycle can reduce and effectively cancel this effect. Increased heat transfer as experienced in the high velocity fixed bed work here and in fluidized bed conditions also increase the mass transfer of oxygen through the gas film to the surface. If this mass transfer is faster than the rate of oxygen diffusing out of the lattice, coke formation will occur. Also, the chemical reactions proposed by Monazam et al. [20] appear to be consistent with the data. Additionally, based upon these findings, a small scale fixed bed unit does not appear to be practical for an early demonstration due to the decay in the rate in these fixed bed units. 


\section{$381 \quad$ Nomenclature}

$382 b$ - the stoichiometric coefficient in Abad model

$383 C_{i}$ - the reacting gas concentration in Abad model where $i$ - denotes gas species $\mathrm{CH}_{4}, \mathrm{CO}$ or $\mathrm{H}_{2}$

$384 \quad k$ - rate constant in current work

$385 k_{l}$ - rate constant for the first mechanism in Monazam et al. model

$386 k_{2}$ - rate constant for the first mechanism (min. ${ }^{-n}$ ) in Monazam et al. model

$387 k_{s i}$ - the reaction rate in Abad model

$388 n$ - solids reaction order

$389 \quad r_{g}$ - the grain radius in Abad model

390 Re - Reynolds Number

$391 R_{T}$ - overall reaction rate in current work

$392 R_{f}$ - rate of the fact reaction in current work

$393 R_{s}$ - rate of the slow reaction in current work

$394 S_{A}$ - the particle surface area in current work

395 Sh - Sherwood Number

$396 t$ - time

$397 \mathrm{~T}$ - the temperature $(\mathrm{K})$ in Monazam et al. model and in current work

$398 u$ - gas velocity in current work

$399 w_{1}$ - weight factor for the first mechanism in Monazam et al. model

$400 w_{2}$ - weight factor for the second mechanism in Monazam et al. model

$401 X$ - conversion of $\mathrm{Fe}_{2} \mathrm{O}_{3}$ in Abad model and current work

$402 X_{1}$ - conversion of $\mathrm{Fe}_{2} \mathrm{O}_{3}$ by $\mathrm{R}_{1}$ at any time $\mathrm{t}$ in Monazam et al. model

$403 X_{2}$ - conversion of $\mathrm{Fe}_{2} \mathrm{O}_{3}$ by $\mathrm{R}_{2}$ at any time $\mathrm{t}$ in Monazam et al. model

$404 X_{\infty}$ - equilibrium conversion in Monazam et al. model

$405 \tau_{i}$ - time for complete conversion in Abad model

$406 \rho_{m}$ - the molar density of $\mathrm{Fe}_{2} \mathrm{O}_{3}$ in Abad model 
$\mathrm{y}_{\mathrm{CH} 4}$ - the methane mole fraction in Monazam et al. model

$y_{g}$ - gas mole fraction in current work

\section{Acknowledgements}

The authors acknowledge the Department of Energy for funding the research through the office of Fossil Energy's Gasification Technology and Advanced Research funding programs. Special thanks go to Duane Miller and Rich Eddy of URS Energy \& Construction, Inc. for their assistance with experimental work and data. The authors also extend thanks to Dr. George Richards and Dave Huckaby for their input in numerous discussions.

\section{Disclosure}

The U.S. Department of Energy, NETL and REM contributions to this report were prepared as an account of work sponsored by an agency of the United States Government. Neither the United States Government nor any agency thereof, nor any of their employees, makes any warranty, express or implied, or assumes any legal liability or responsibility for the accuracy, completeness, or usefulness of any information, apparatus, product, or process disclosed, or represents that its use would not infringe privately owned rights. Reference herein to any specific commercial product, process, or service by trade name, trademark, manufacturer, or otherwise does not necessarily constitute or imply its endorsement, recommendation, or favoring by the United States Government or any agency thereof. The views and opinions of authors expressed herein do not necessarily state or reflect those of the United States Government or any agency thereof.

The authors declare no competing financial interest.

\section{References}

1. Ciferno J, Litynski J, Brickett L, Murphy J, Munson R, Zaremsky C, Marano J, Strock J, "DOE/NETL Advanced CO2 Capture R\&D Program: Technology Update", U.S Department of Energy 2011.

2. Terry F. Wall, "Combustion processes for carbon capture", Proceedings of the Combustion Institute 31 (2007) 31-47.

3. Fan, L. S., "Chemical Looping Systems for Fossil Energy Conversion", John Wiley and Sons, NJ, 2010.

4. Cho, P.; Mattisson, T.; Lyngfelt, A. Carbon formation on nickel and iron oxide containing oxygen carriers for chemical-looping combustion. Ind. Eng. Chem. Res. 2005, 44, 668-676.

5. Mattisson, T., Lyngfelt, A., and Cho, P., "Possibility of using iron oxide as an oxygen carrier for combustion of methane with removal of $\mathrm{CO} 2$ - Application of chemical looping combustion", 
Fifth International Conference on Greenhouse Gas Control Technologies, Cairns, Australia, 2000, 205-210.

6. Son, S. R. and Kim, S. D. "Chemical Looping Combustion with $\mathrm{NiO}$ and $\mathrm{Fe} 2 \mathrm{O} 3$ in a Thermobalance and Circulating Fluidized Bed Reactor with Double Loop", Ind. Eng. Chem. Res., 2006, 45, 2689-2696.

7. Abad, A., Adanez, J., Garcia-Labiano, F., de Diego, L. F., Gayan, P. and Celaya, J., "Mapping of range of operational conditions for $\mathrm{Cu}$-, $\mathrm{Fe}$-, and Ni-based oxygen carriers in chemical looping combustion", CES, 62, 2007, 533-549

8. Abad, A., Mattisson, T., Lyngfelt, A., and Johansson, M., "The use of iron as oxygen carrier in a chemical-looping reactor", Fuel 86, 2007, 1021-1035

9. Abad, A., Adanez, J., Cuadrat, A., Garcia-Labiano, F., Gayan, P. and de Diego, L. F., "Kinetics of redox reactions of ilmenite for chemical looping combustion", CES, 66, 2011, 689-702

10. Adanez, J., Garcia-Labiano, F., de Diego, L. F., Gayan, P., Celaya, J. and Abad, A., "Characteristics of oxygen carriers for chemical-looping combustion", Greenhouse Gas Control Technologies, Vol. 1, ed.: E.S. Rubin, D. W. Keith and C.F. Gilboy, Elservier Ltd., 2005

11. Cho, P., Mattisson, T. and Lyngfelt, A., "Reactivity of iron oxide with methane in a laboratory fluidized bed - application of chemical looping combustion", Proceedings of the 7th International Conference on Circulating Fluidized Beds (CFB-7), Niagara Falls, Ontario, May 5-8, 2002; pp 599-606

12. Gayan, P., Pans, M. A., Ortiz, M., Abad, A., de Diego, L. F., Garcia-Labiano, J. and Adanez, J., "Testing of highly reactive impregnated Fe2O3/A12O3 oxygen carrier for a SR-CLC system in a continuous CLC unit”, Fuel Processing Technology 96, 2012, 37-47

13. Go., K. S., Son, S. R. and Kim, S. D., "Reaction kinetics of reduction and oxidation of metal oxides for hydrogen production", IJHE 33, 2008, 5986-5995

14. He., F., Wang, H. and Dai, Y., "Application of Fe2O3/Al2O3 composite particles as oxygen carrier of chemical looping combustion", Jour. Natural Gas Chemistry 16, 2007, 155-161

15. Johansson, M., Mattisson, T. and Lyngfelt, A., "Investigation of $\mathrm{Fe} 2 \mathrm{O} 3$ with $\mathrm{MgAl} 2 \mathrm{O} 4$ for chemical-looping combustion”, Ind. Eng. Chem. Res. 2004, 43, 6978-6987

16. Leion, H., Lyngfelt, A., Johansson, M., Jerndal, E. and Mattisson, T., "The use of ilmenite as an oxygen carrier in chemical-looping combustion", Chem. Eng. Res and Des., 86, 2008, 1017-1026

17. Mattisson, T., Johansson, M. and Lyngfelt, A., "Multicycle reduction and oxidation of different types of iron oxide particles- Application to chemical-looping combustion”, Energy Fuels 2004, $18,628-637$.

18. Mendiara, T., Abad, A., de Diego, L. F., Garcia-Labiano, J. Gayan, P. and Adanez, J., "Use of an Fe-based residual from alumina production as an oxygen carrier in chemical-looping combustion”, Energy Fuels, 2012, 26, 1420-1431 
19. Moghtaderi, B. and Song, H., "Reduction of Properties of Physically mixed metallic oxide oxygen carriers in chemical looping combustion", Energy Fuels, 2010, 24, 5359-5368

20. Monazam, E. R., Breault, R. W., Siriwardane, R., Richards, G. and Carpenter, S., "Kinetics of the reduction of hematite $(\mathrm{Fe} 2 \mathrm{O} 3)$ by methane $(\mathrm{CH} 4)$ during chemical looping combustion: A global mechanism" Chemical Engineering Journal, Volume 232, October 2013, Pages 478-487

21. Son, S. R. and Kim, S. D., " Chemical-looping combustion with inherent CO2 separation in annual circulating fluidized bed reactor", Proceedings $9^{\text {th }}$ International Conference on Environmental Science and Technology, 2005, B-871 - B-876

22. Zhang, J., Gou., Q., Liu, Y. and Cheng, Y., "Preparation and characterization of Fe2O3/Al2O3 using the solution combustion approach for chemical looping combustion", Ind. Eng. Chem. Res. 2012, 51, 12773-12781

23. Y. Ku, H-C. Wu, P-C. Chiu, Y-H. Tseng, Y-L. Kou, Methane combustion by moving bed fuel reactor with Fe2O3/A12O3 oxygen carriers, Applied Energy 113, 1909-1915

24. Y. Zhang, E. Doroodchi, B. Moghtaderi, "Chemical looping combustion of ultra low concentration of methane with Fe2O3/Al2O3 and CuO/SiO2", Applied Energy 113, 1916-1923

25. Monazam, E. R., Breault, R. W., Siriwardane, R., and Miller, D., “Thermogravimetric Analysis of Modified Hematite by Methane (CH4) for Chemical-Looping Combustion: A Global Kinetics Mechanism", Ind. Eng. Chem. Res., 2013, 52 (42), pp 14808-14816

26. Monazam, E. R., Breault, R. W. and Siriwardane, R., "Reduction of hematite (Fe2O3) to wüstite $(\mathrm{FeO})$ by carbon monoxide (CO) for chemical looping combustion" Chemical Engineering Journal, In Press, Accepted Manuscript, Available online 21 December 2013

27. Breault, R. W. and Huckaby, E. D., "Parametric behavior of a CO2 capture process: CFD simulation of solid-sorbent CO2 absorption in a riser reactor", Applied Energy, 112 (2013) 224234

28. Chatterjee, A., Beyond the Blast Furnace, CRC Press, 1994, 2-18.

29. Kunii, D. \& Levenspiel, O. Fluidization Engineering, Krieger Publishing, Huntington, New York, 1977. 


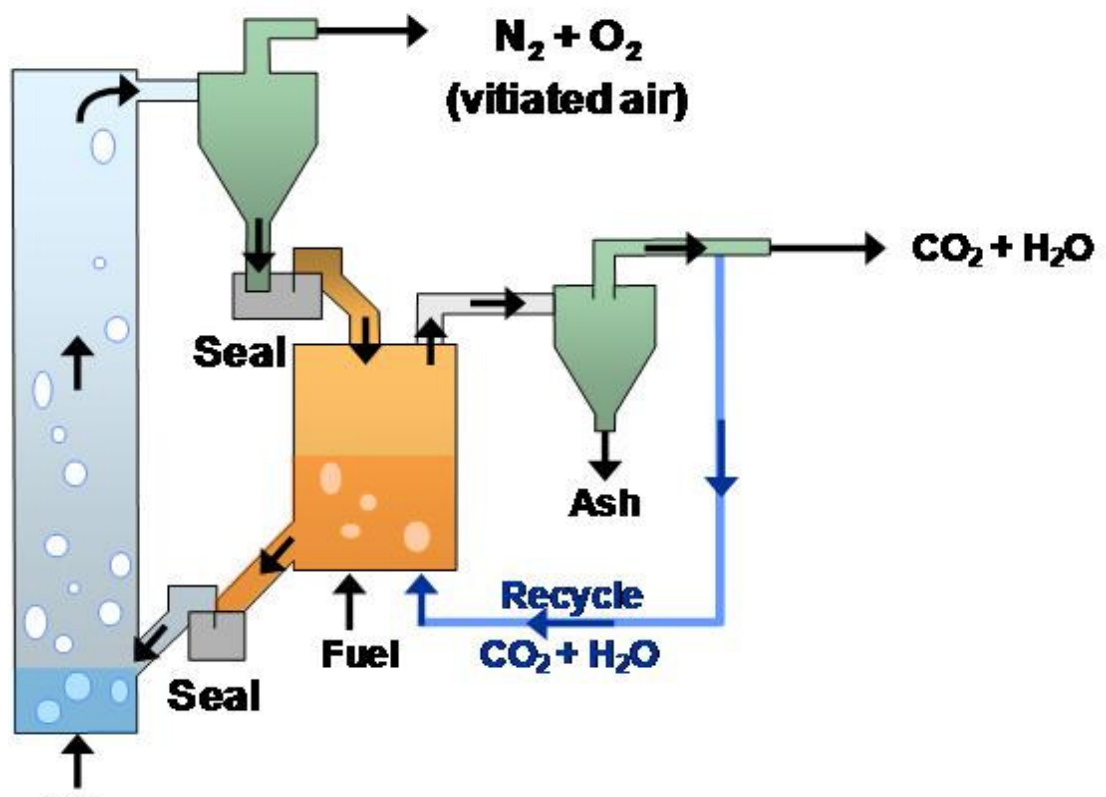

Fig. 1. Chemical Looping Concept Configuration. 


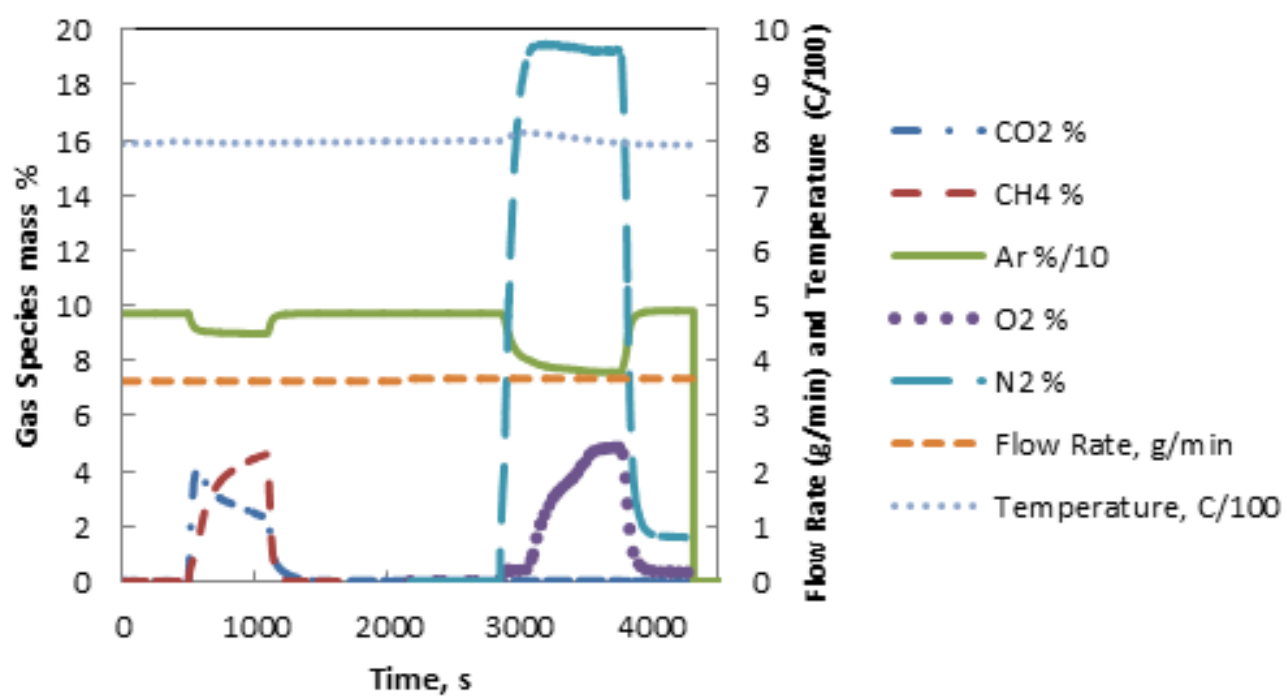

511

512

operating cycle for experiments

Fig. 2. Typical 

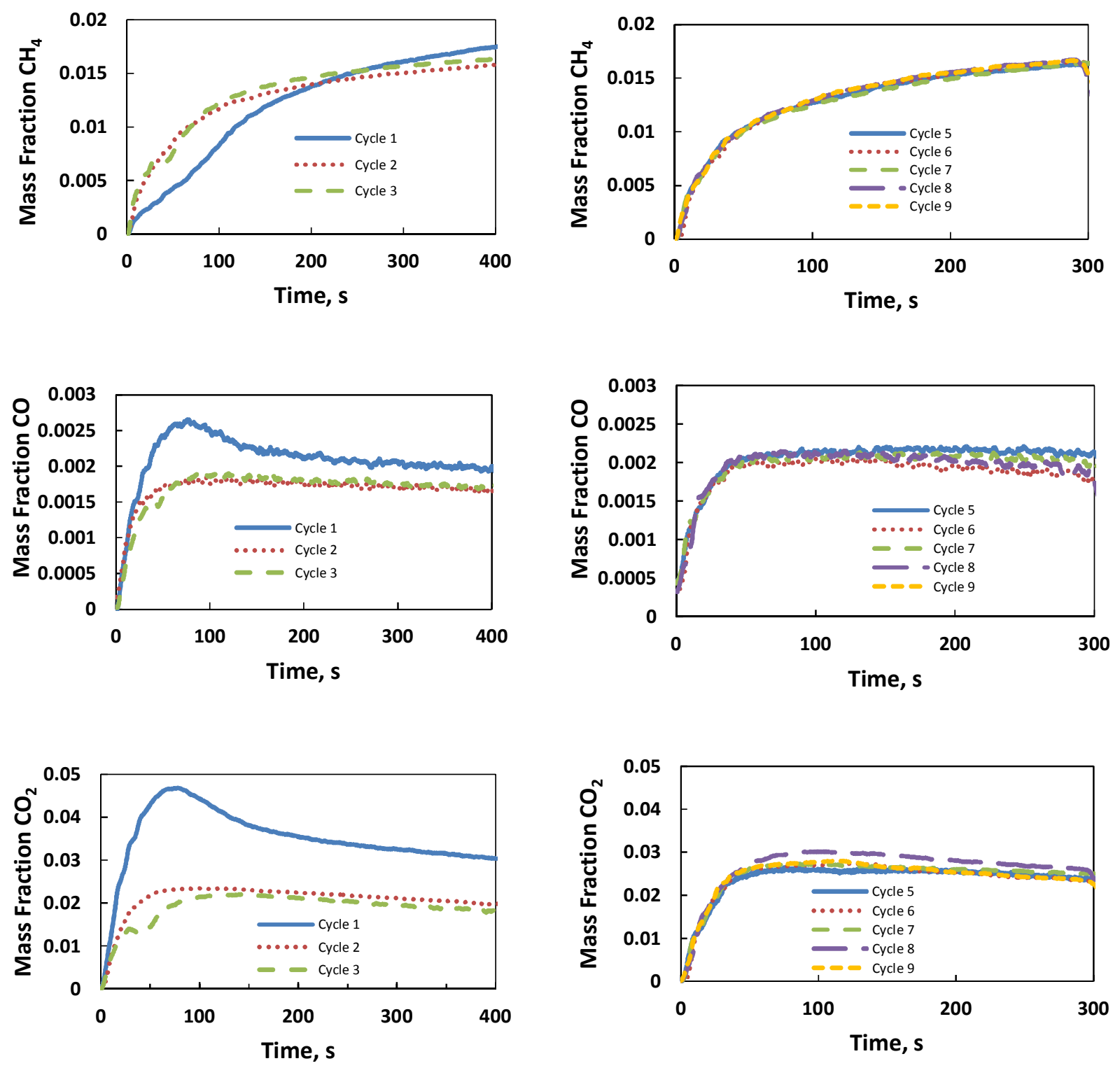

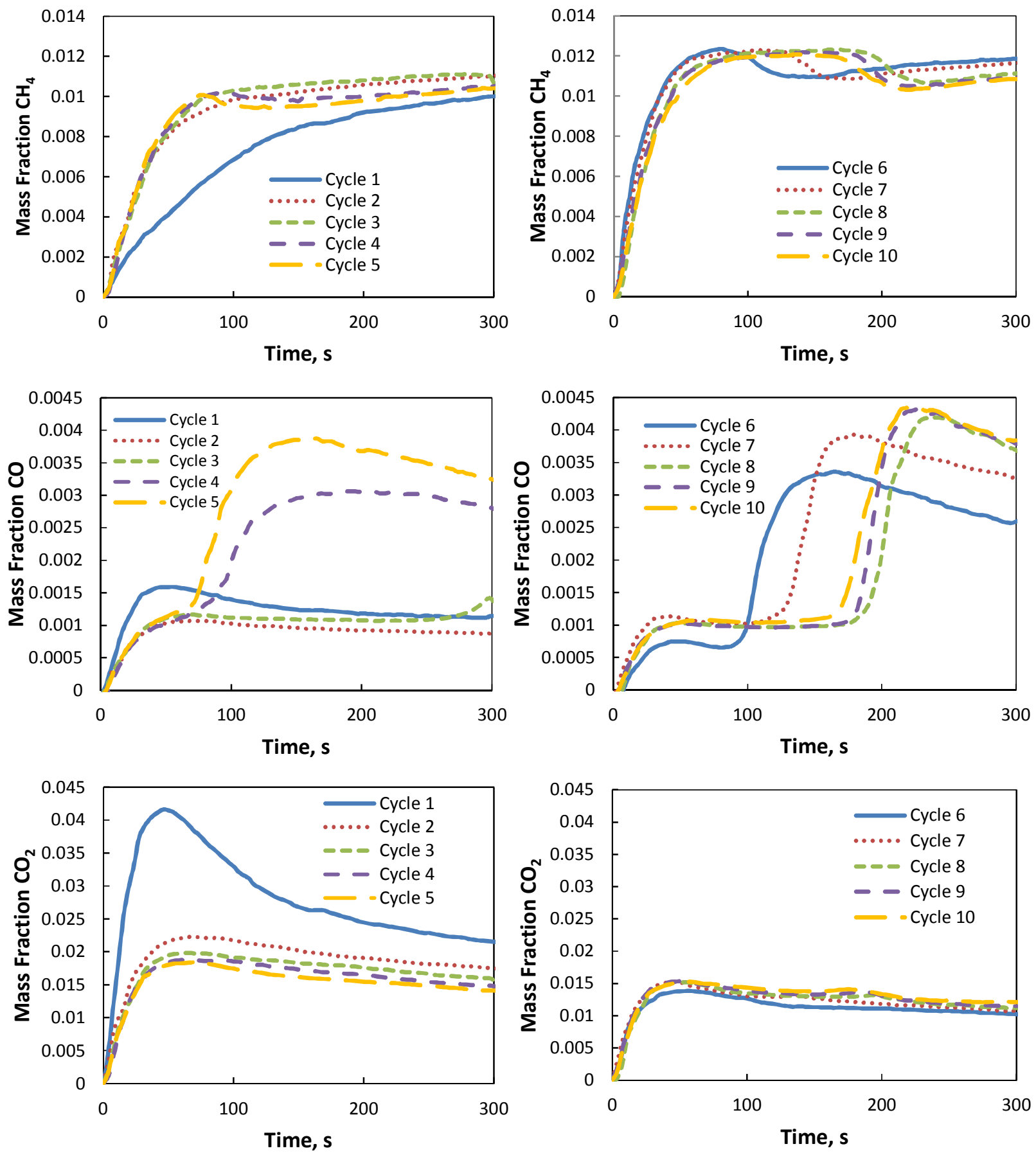

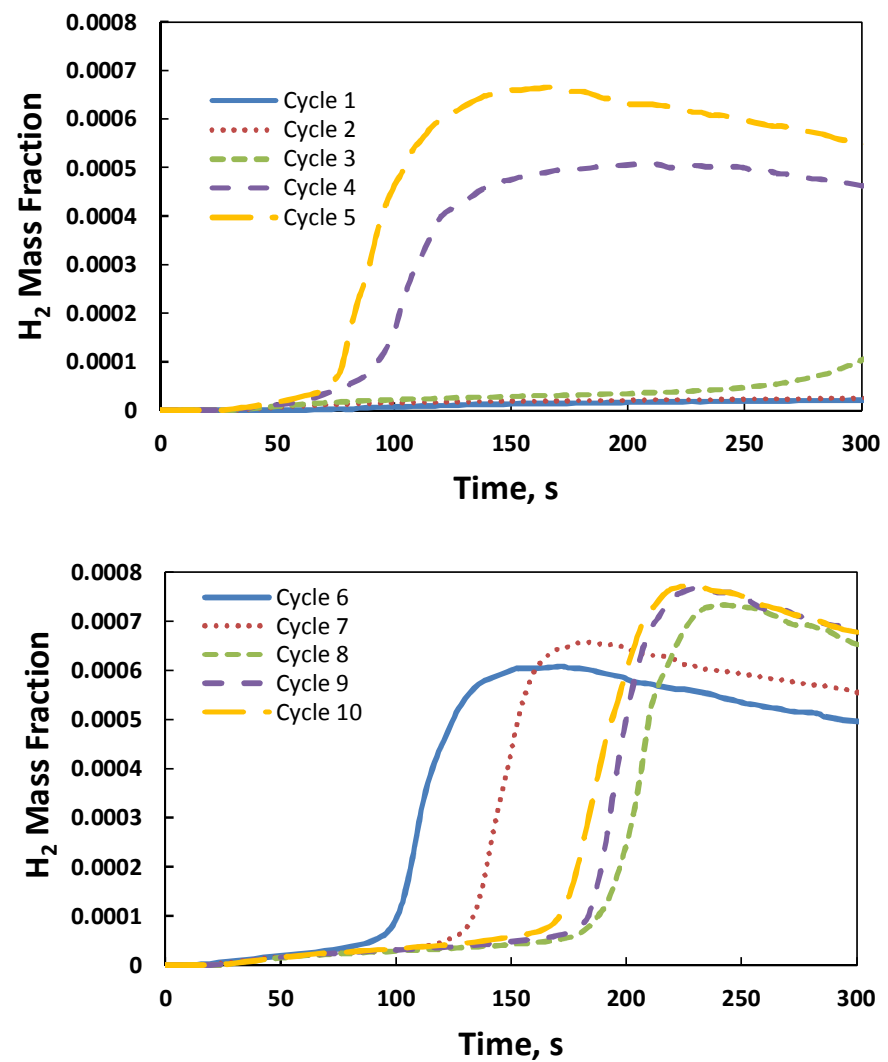

Fig. 5. $\mathrm{H}_{2}$ mass fractions for Series 2 


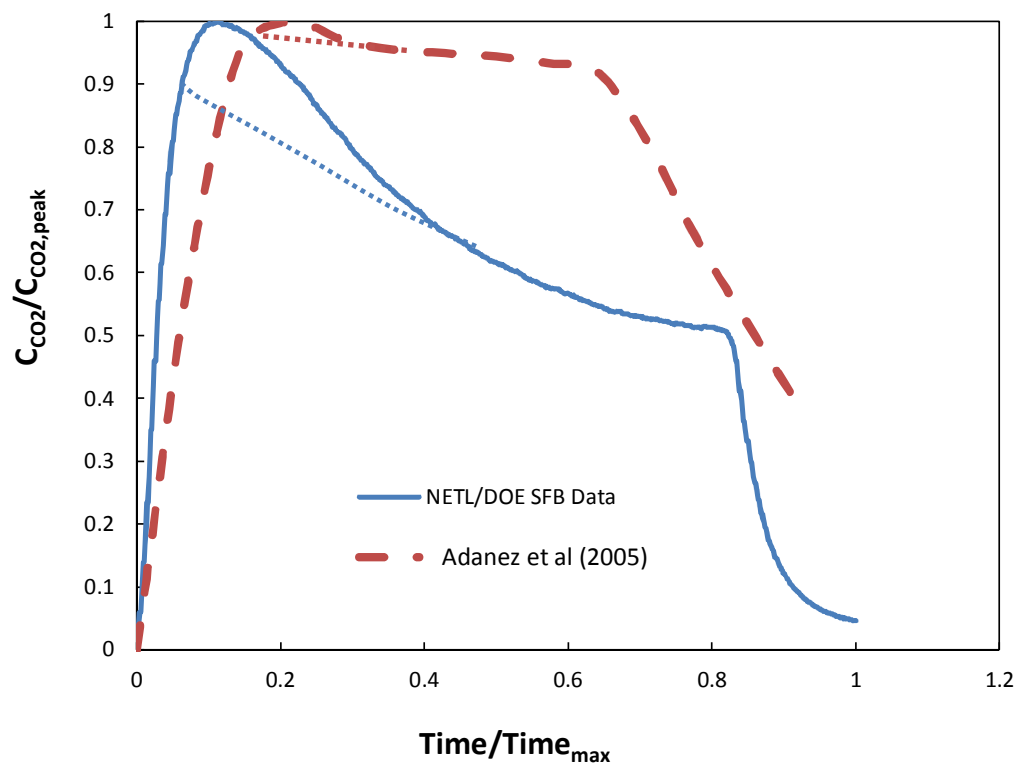

Fig. 6. Comparison of $\mathrm{CO} 2$ exit gas profiles in other reactors 


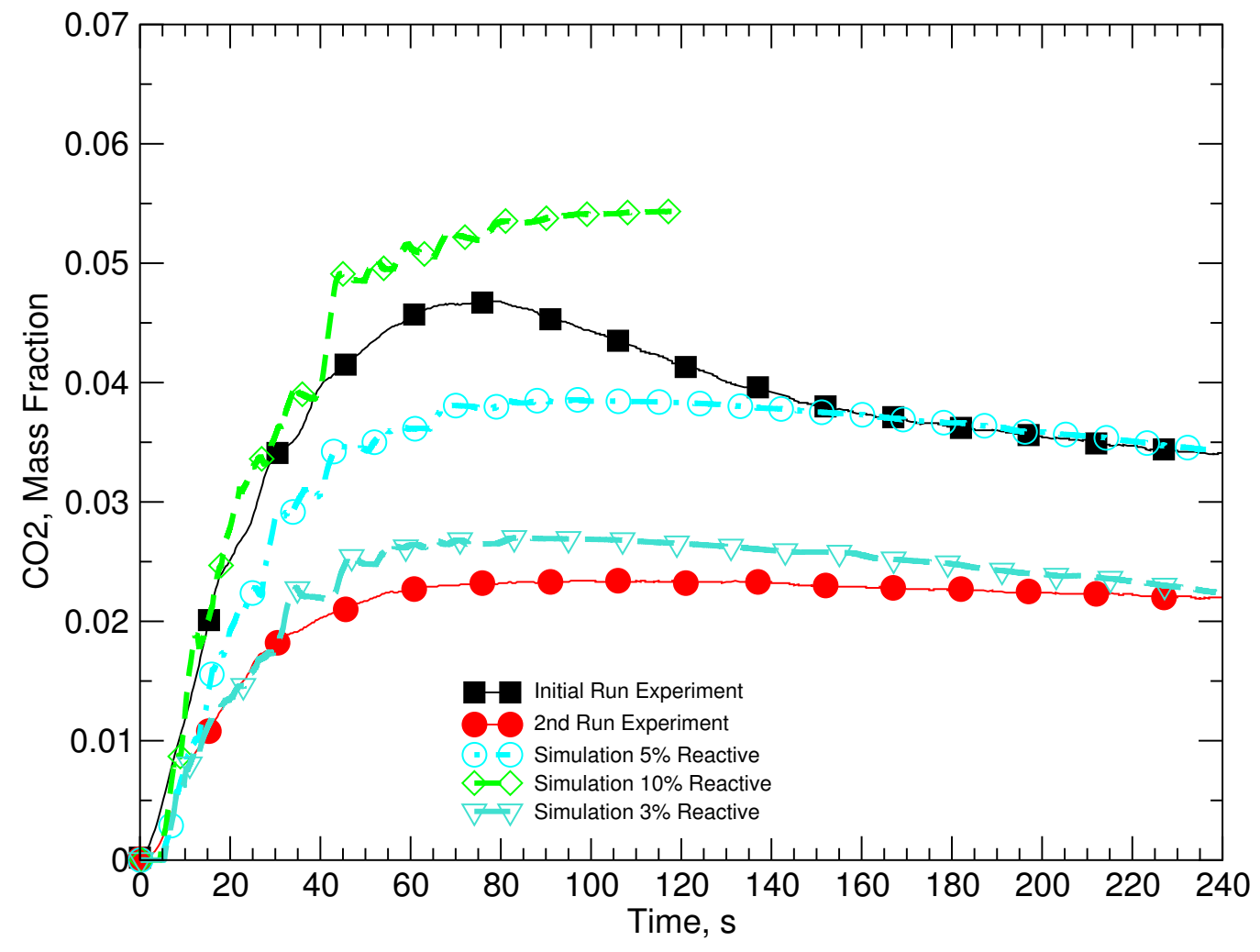

529 

approximately $10 \%$, the weight loss associated with a final conversion of the $\mathrm{Fe}_{2} \mathrm{O}_{3}$ to $\mathrm{FeO}$.

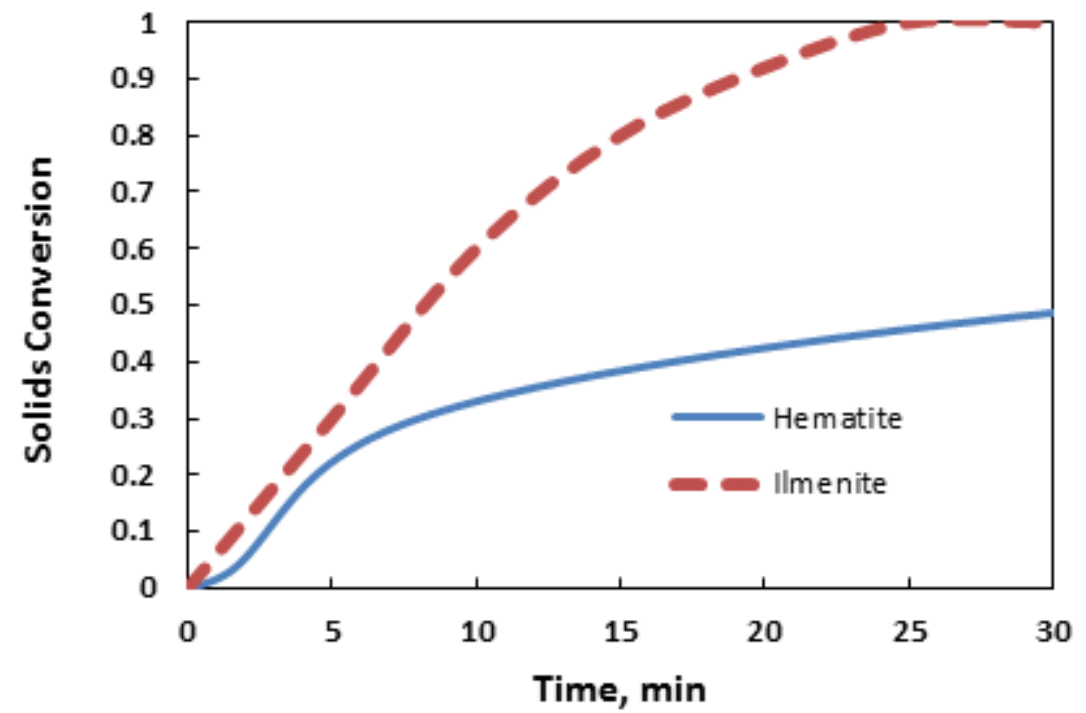

531

532 Fig. 8. A comparison of the TGA results of the hematite used in the current work to TGA data for 533 Ilmenite (Abad [9]). 


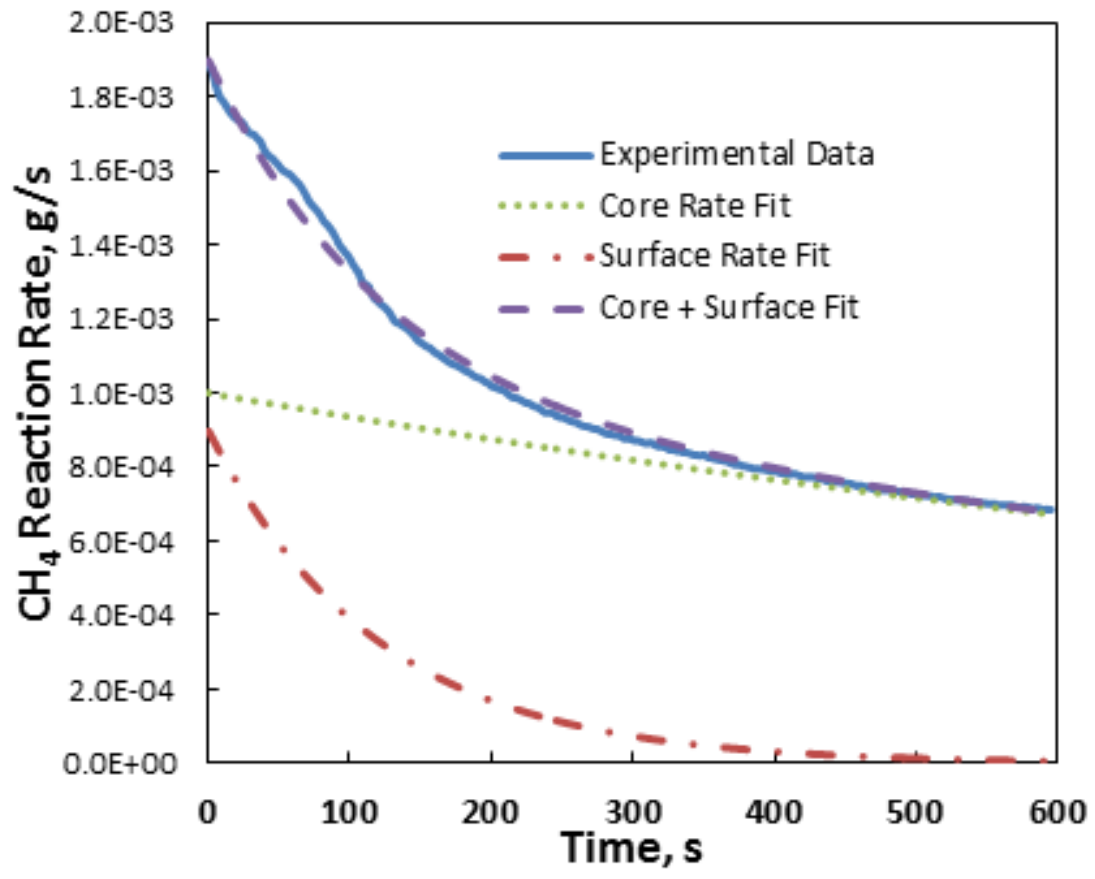

536

Fig. 9. Partitioning of the data into a fast and slow set for analyzing the process 


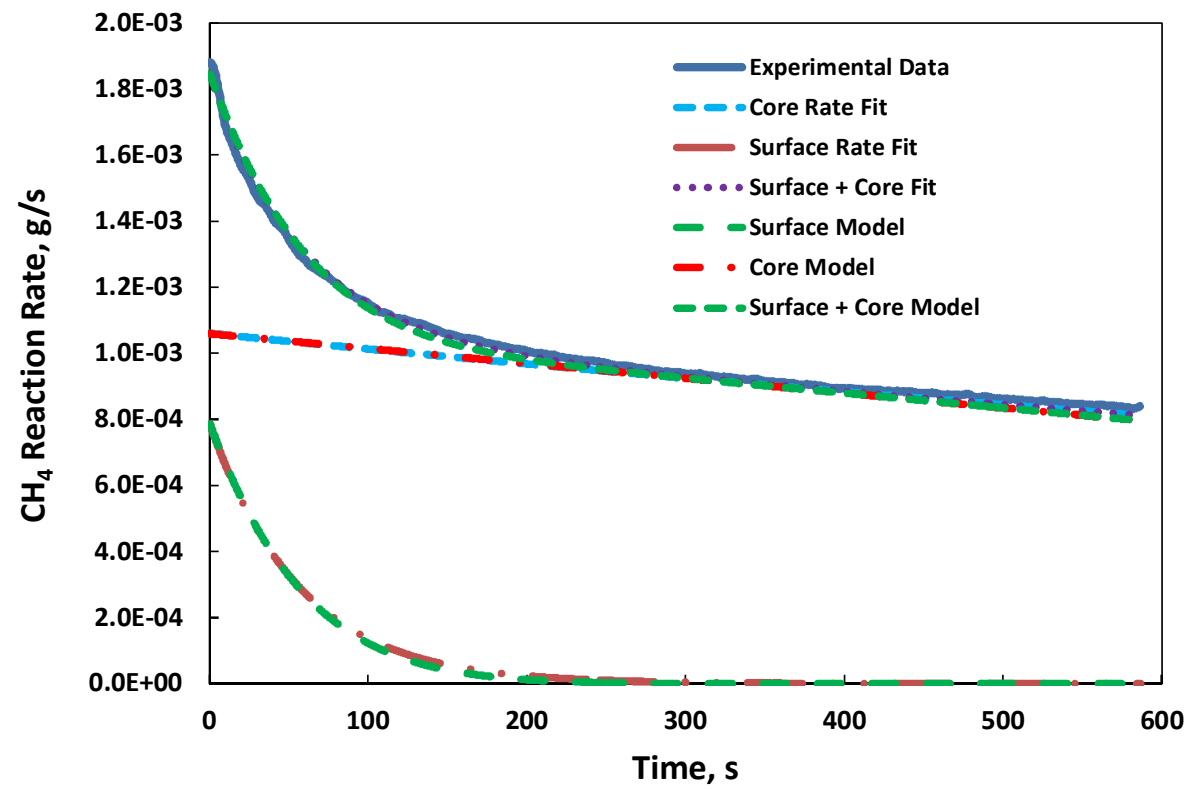

538

539 Fig. 10. Comparison of rate models with experimental data for Series 1, Cycle 1.

540 


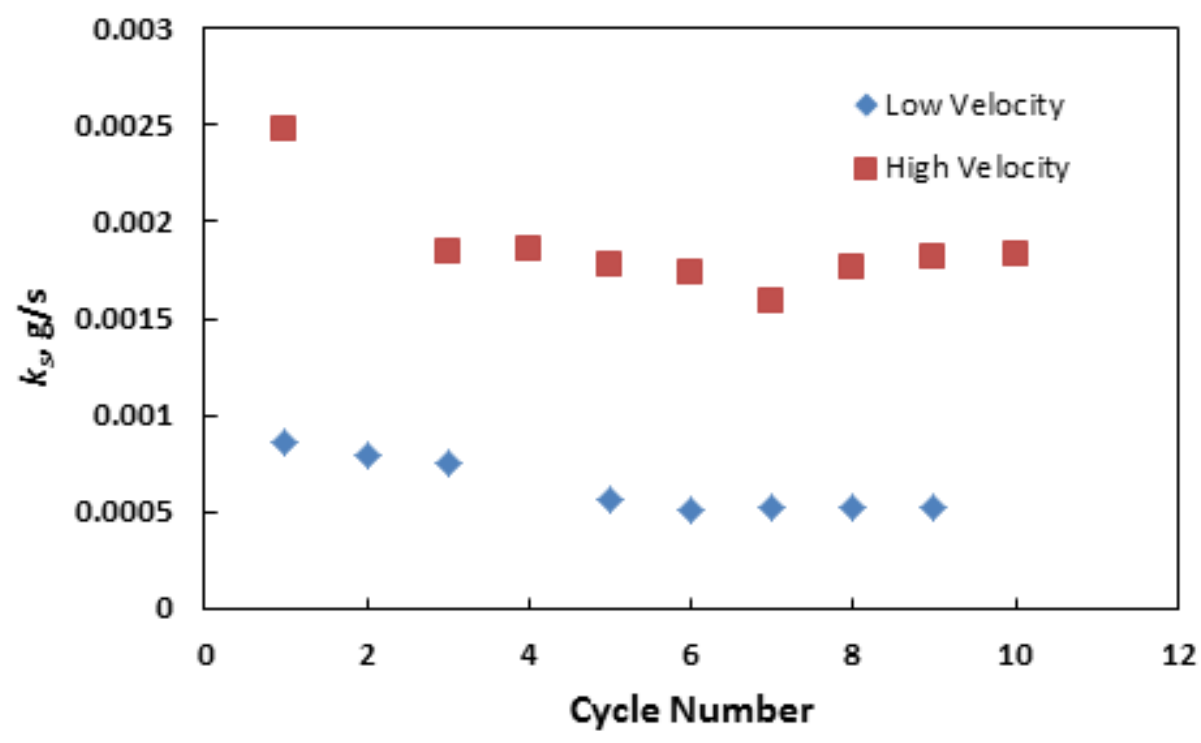

Fig. 11. Reaction rate constant for surface reaction 


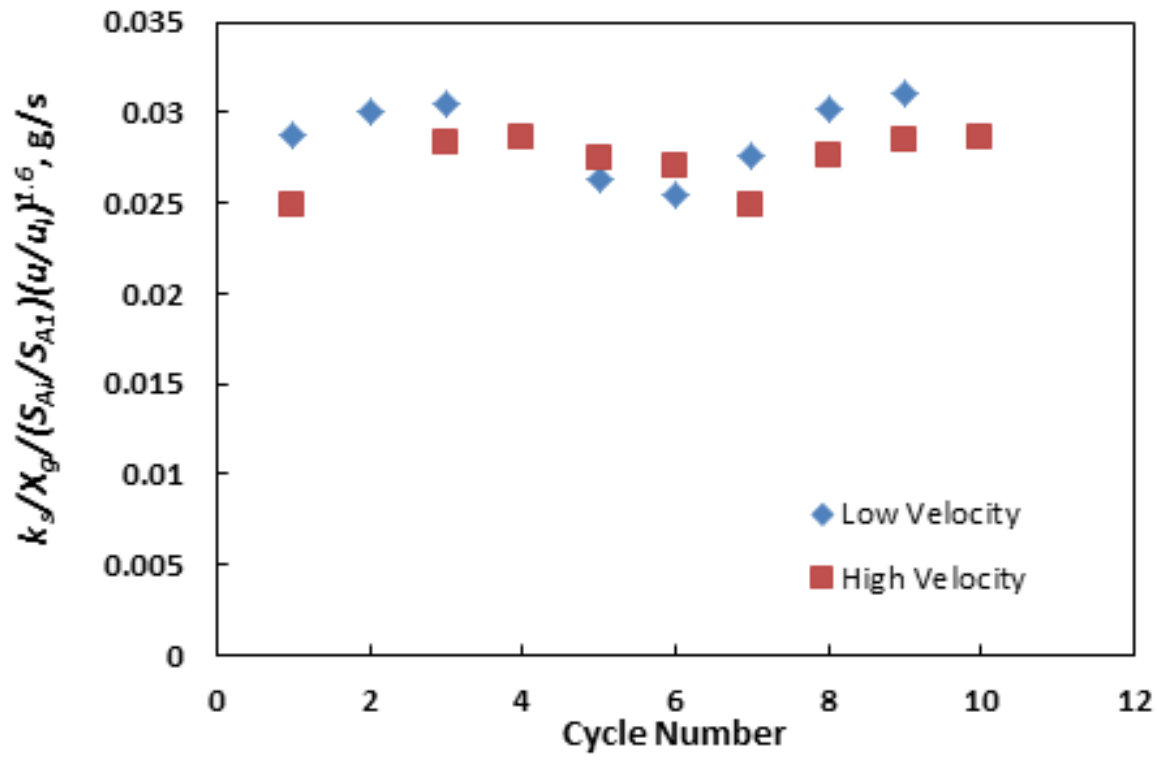

545 Fig. 12. Reaction rate constant for surface reaction corrected for gas velocity effects, inlet gas 546 concentration and particle surface area 
548

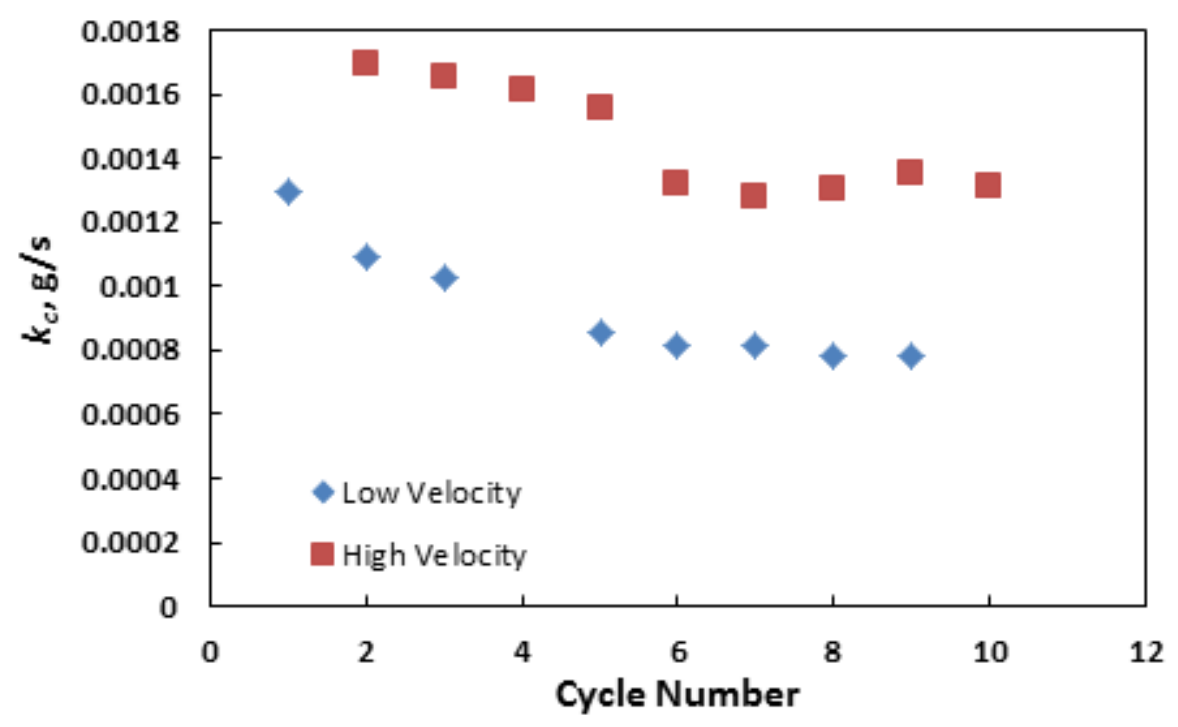

549 Fig. 13. Reaction rate constant for core reaction

550 


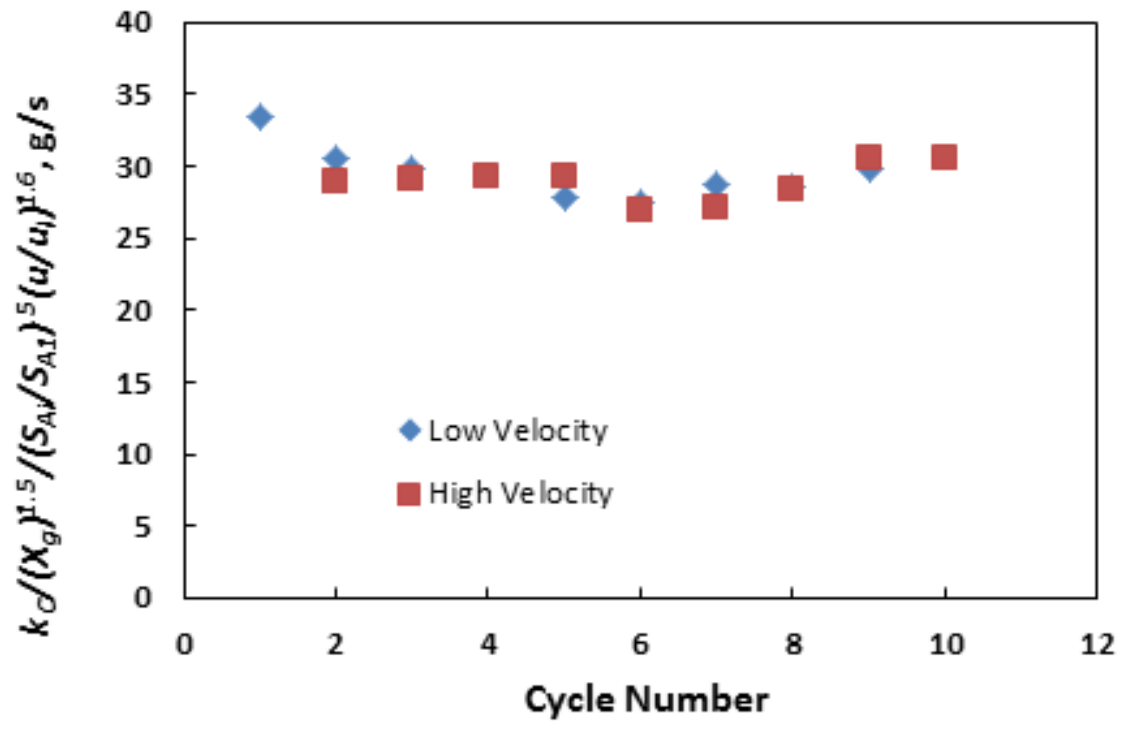

551

552 Fig.14. Reaction rate constant for core reaction corrected for gas velocity effects, inlet gas 553 concentration and particle surface area 

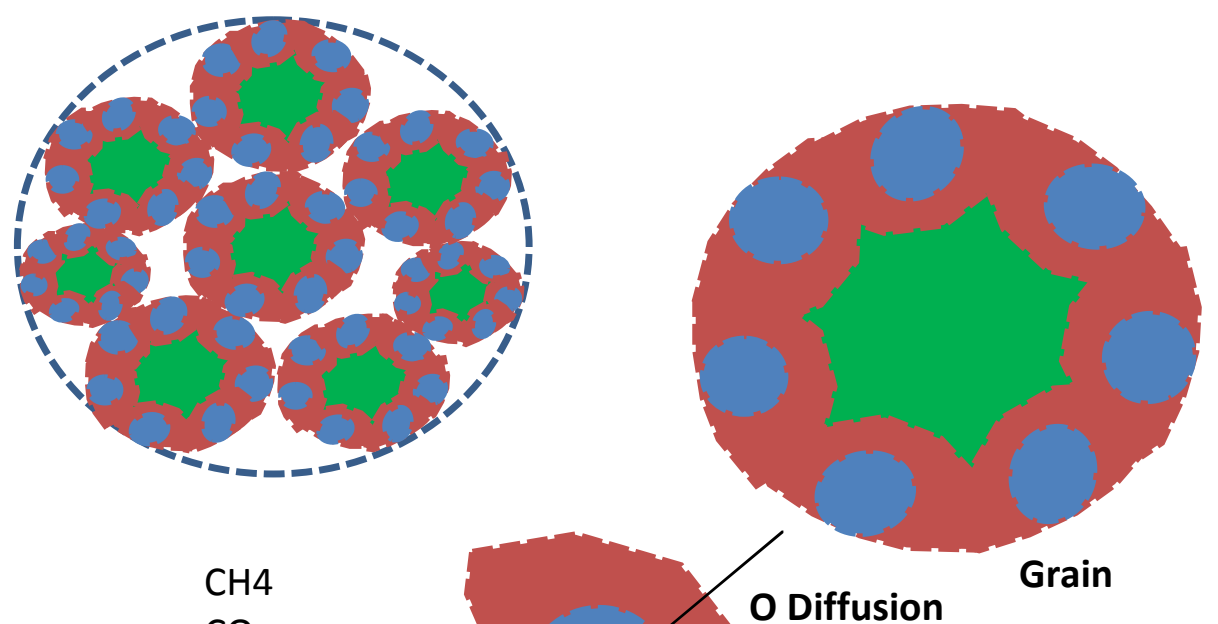

555

Gas Products

$\mathrm{CO}$

$\mathrm{H} 2$

CO. $\mathrm{CO} 2$ and $\mathrm{H} 2$

556 Fig. 15. Particle grain model with oxygen diffusion from the lattice core

557

558 